\title{
造血.幹細胞移植患者が退院後に遭遇する困難と 移植後の生活を再構築できる要因
}

\author{
石田 和 子, ${ }^{1}$ 萩 原薫, ${ }^{1}$ 石 田 順子 ${ }^{2}$ \\ 赤 石 美佐代, ${ }^{2}$ 吉 田 久美子, ${ }^{2}$ 平 井 和 恵 ${ }^{3}$ \\ 川田悦夫, ${ }^{4}$ 神田清子 5
}

\section{要 旨}

【背景・目的】造血肝細胞移植を受けた患者が退院後に遭遇する困難と移植を受けたことで変化した生活を 再構築できる要因を明らかにすることを目的とした。【対象と方法】G 病院血液内科にて移植を受けた患 者で順調に経過し, 重篤な移植片対症候群や免疫不全がない 13 名に半構成的面接を行った. 面接内容を逐語 録に起こし, 質的帰納的方法を参考に, 患者の言動から造血幹細胞移植患者が退院後に遭遇する困難と移植 後の生活を再構築できる要因に関する言動をコード化し類似性に従いサブカテゴリー, カテゴリーと抽象化 を行った.【結 果】退院後に遭遇する困難は『病気の不確実性』『変化した生活が辛く哀しい』『今までと 違う体力』『身体的変化』『周囲への気兼ね』のカテゴリーが抽出された. 移植後の生活を再構築できる要因と しては『前向きに生きる決意』『夫婦の価値観の変化』『自分のペースで生活』『経済生活の基盤の変化』『苦 悩を支えられた体験』のカテゴリーが抽出された。【結 語】移植看護において移植を受けた患者が退院後 の生活を再構築するためには，患者を支えるサポートが重要であることが示唆された. (Kitakanto Med J $2005 ; 55: 97 \sim 104)$

キーワード : 造血幹細胞移植患者, 困難, 生活の再構築, 日常生活

\section{はじめに}

造血幹細胞移植 (以下移植とする) は, 白血病や再生不 良性貧血などの難治性血液疾患における根治的治療の一 つとして行われてきている.これまで, 移植患者の心理 面に関する研究は，䑨菌室入室中から退室などの心理的 な変化㳊関する研究, ${ }^{1-3}$ 移植患者の QOL (Quality of Life）について尺度を用いて日常生活を論じている研 究 ${ }^{4-6}$ 移植患者の心理を段階每にテストを用いて調査し 患者ケアを考察している,7,8 患者へのオリエンテーショ ン を検討した研究がなされている。これらの研究は, 移 植患者の入院中の生活を中心に研究がなされている.し かし, 移植患者は退院後に身体, 心理, 社会的な側面の問
題に対処することが多く困難に遭遇する．

筆者らが行った研究, ${ }^{10}$ では骨髄移植患者は退院後, 心 理的な側面, 役割の変化など多くの問題を抱えて生活し ていることが明らかになった．また，移植患者の希望に 関する研究では移植に対して『助かること』『生き残る』 などの移植治療に希望を抱いていることが明らかになっ た. ${ }^{11}$ しかしながら, 移植治療は, 移植片対宿主病 (以下 GVHD とする), 間質性肺炎などの感染症, ${ }^{12}$ さらに大量 抗がん㓮による皮膚の変化などの副作用により患者法苦 悩に直面する. その後, 移植により生命の危機から脱し 長期生存する患者が増えてきている. ${ }^{13}$ 患者の退院後の 生活は，原疾患および移植が生命を脅かす出来事に直面 した後の生活は満ち足りた意義深いものである. ${ }^{14}$ その

1 群馬県䏍橋市昭和町3-39-15 群馬大学医学部附属病院看護部 2 群馬県前橋市昭和町3-39-15 群馬大学医学系研究科看護学 専攻 3 神奈川県横浜市金沢区福浦3-9 横浜市立大学看護短期大学部 4 群馬県前橋市昭和町 3-39-15 群馬大学医学部附属 病院総合診療部

5 群馬県前橋市昭和町3-39-22 群馬大学医学部保健学科

平成17年 2 月 18 日 受付

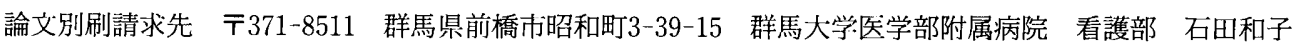


反面，移植合併症により身体的症状がある場合において QOL は著しく低下している. ${ }^{15}$ 外崎は移植に伴う影響は 全身性で長期に渡り個別性が大きく予測が困難であると

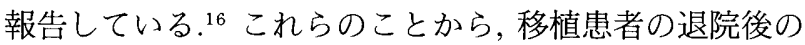
生活する上で遭遇する困難を探求することでこれから移 植をする人が退院後の生活が円滑に過ごせるような看謢 実践を提供するための基本的な知識を提供する指標とな り重要な事柄である。そこで，本研究の目的は移植を受 けた患者が退院後に遭遇する困難とはどのようなことな のか，また移植後患者が変化した生活を再構築できる要 因はなんなのかを明らかにし看護実践したので報告す る.

\section{研 究 方 法}

\section{研究デザインと研究の前提}

本研究は㷌納的アプローチによる質的因子探索型研究 である，質的研究とは，人間に関するありのままの経験 を記述することなくしては成り立つことのできない前提 に基づく研究である. ${ }^{17}$ 研究者はその前提に立ち, 移植を 受け無事に退院することができた患者の経験をありのま まに記述し，その中からそこに存在する現象が何かを探 求することとした

\section{用語の定義}

困難とは, 本研究では身体, 心理, 社会的な側面の問題 に対処するとき時に生ずる出来事とする. 生活の再構築 とは，本研究では困難に遭遇したときに，変化した環境 に適応するための新しい価值観, 考え, 行動とする.

\section{対象}

$\mathrm{G}$ 病院血液内科にて移植を受けた患者で順調に経過 し, 重篤な移植片対症候群や免疫不全がなく, 歩行にて 自分で外来通院ができ，医師，看護師長より面接可能で あると判断された 13 名の患者とした。 なお，倫理的配慮 から心理的に不安定な患者は対象から除外した。

\section{データ収集方法}

移植を受けて退院した患者の主観に迫るために移植を 受けた時の状況および経過を受け持ち看護師の立場で移 植時から退院までの期間において医師・看護師・家族と の関わりを観察した．また，入院期間中に患者とは人間 関係の確立は行えていた。退院後には外来受診時に日常 生活を行う上の問題について半構成的面接法を用いて 1997 年 4 月〜 6 月の期間にデー夕収集した．面接時，研 究者は聞く立場に徹し患者が日ごろ感じていることに耳 を傾けた．面接内容は「退院後の生活で何か困ったこと はありますか」病気をする前と今では何か違いがありま すか」など尋ねた，面接内容は対象者に許可を得てテー プレコーダーに録音し逐語録として再現した.さらに， カルテ, 看護記録，退院時要約の記録から対象者の年歯, 職業, 家族構成, 受診経過, 診断名に関する情報を収集し 基礎資料とした。

\section{データ分析方法}

得られたデータの分析は，質的帰納的分析法18-20を参 考に以下の手順で行った. (1)収集されたデータを繰り返 し読み「移植患者が退院後に遭遇する困難な体験と移植 後の生活を再構築する要四」と思われる部分のまとまり ごとに抽出する. (2)文章の前後の文脈や意味を読み取り ながら(1)を修正しコードとする. (3)観察内容を参考にし ながらコードを検討し類似するものを集めサブカテゴ リーとする. (4)サブカテゴリーの類似するものを集めて カテゴリーとする. 分析にあたっては移植看護における 研究的な視点を持ち, 質的研究方法の実践者である看護 研究者にスーパーバイスを受けながら行った。

\section{倫理的配慮}

対象者に研究目的，方法，収集したデー夕は研究の目 的のみに使用し個人名などは秘密綮导することを文書に て説明をした．さらに本研究に参加しなくても治療预よ び看護に影響を受けることのない事，いつでも研究への

表 1 対象者の背景

\begin{tabular}{|c|c|c|c|c|c|c|c|c|}
\hline \multirow{3}{*}{$\mathrm{A}$} & \multirow{3}{*}{$\begin{array}{c}\text { 年齢 } \\
50 \\
5\end{array}$} & \multirow{3}{*}{$\begin{array}{c}\text { 病 名 } \\
\mathrm{AML}\end{array}$} & \multirow{3}{*}{$\begin{array}{c}\text { 性別 } \\
\text { 男 }\end{array}$} & \multirow{2}{*}{ 移植後経過年数 } & \multicolumn{2}{|c|}{ 仕 事 の 変 化 } & \multirow{2}{*}{\multicolumn{2}{|c|}{ キーパーソン }} \\
\hline & & & & & \multirow{2}{*}{$\begin{array}{lll}\text { 移 } & \text { 植 } & \text { 前 } \\
\text { 自 } & \text { 由 } & \text { 業 }\end{array}$} & \multirow{2}{*}{$\begin{array}{l}\text { 移 植 後 } \\
\text { 変化なし }\end{array}$} & & \\
\hline & & & & $4 \quad$ 年 & & & \multicolumn{2}{|c|}{ 妻 } \\
\hline B & 22 & CML & 罗 & 3 年 8 ヶ月 & 会 社 員 & 退 & 両 & 親 \\
\hline $\mathrm{C}$ & 25 & MDS & 女 & 3年 2ヶ月 & 会 社 員 & 休 & 両 & 親 \\
\hline $\mathrm{D}$ & 28 & MDS & 女 & 2年 6 ヶ月 & 会 社 員 & 退 & \multicolumn{2}{|c|}{ 夫 } \\
\hline $\mathrm{E}$ & 42 & AML & 女 & 2 年 & 主＼cjkstart婦 & 変化なし & \multicolumn{2}{|c|}{ 夫 } \\
\hline $\mathrm{F}$ & 47 & MDS & 女 & 1年10ヶ月 & 会 社 員 & 退 職 & \multicolumn{2}{|c|}{ 夫 } \\
\hline $\mathrm{G}$ & 38 & MDS & 女 & 8 万 月 & 主 婦 & 変 化な し & \multicolumn{2}{|c|}{ 夫 } \\
\hline $\mathrm{H}$ & 45 & AML & 女 & 1 年3ヶ月 & 公 務 員 & 休 職 & 両 & 親 \\
\hline I & 57 & NHL & 女 & 4 年 1 ヶ月 & 教 & 退 & 子 & 供 \\
\hline $\mathrm{J}$ & 61 & NHL & 男 & 1 年 5 ヶ月 & 会 社 員 & 休 & \multicolumn{2}{|c|}{ 夫 } \\
\hline $\mathrm{K}$ & 42 & NHL & 男 & 年 & 会 社 員 & 休 & \multicolumn{2}{|c|}{ 妻 } \\
\hline $\mathrm{L}$ & 44 & MM & 女 & 1 年 9 ケ月 & 主婦 & 変化な L & \multicolumn{2}{|c|}{ 夫 } \\
\hline M & 54 & MM & 男 & 53 月 & 会＼cjkstart社＼cjkstart員 & 休 & \multicolumn{2}{|c|}{ 妻 } \\
\hline
\end{tabular}


参加を中止できることを説明した上で，研究参加の同意 を文書にて得た

$$
\text { 結果 }
$$

\section{対象者の背景 (表 1)}

本研究の対象者は 13 名で, 性別は男性 5 名, 女性 8 名 であった．対象者の年齢は 20 歳代が 3 名， 30 歳代が 1 名, 40 歳代が 5 名, 50 歳代が 3 名, 60 歳代が 1 名で平均 年齢は 42.7 歳 (SD士12.0) であった. 対象者の疾患は骨 骨道簧形性症候群 4 名, 急性骨髄性白血病・悪性リンパ腫 各 3 名, その他が 3 名であった. 移植後の年数は，5ヶ月
から 4 年1 1 月であり, 仕事の変化があった患者は, 13 名中 9 名であった

\section{移植患者が退院後に遭遇する困難 (表 2)}

分析の結果，『病気の不確実性』『変化した生活が辛く 哀しい』『今までと違う体力』『身体的変化』『周囲への気 兼ね』の 5 つのカテゴリーが抽出された.なお，『』は カテゴリーを示し, サブカテゴリーは〔 〕を示し,コー ドは「」を示した。

『病気の不確実性』のカテゴリーは, 2 つのサブカテゴ リーから構成されていた。

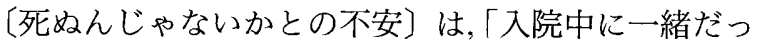

表 2 移植患者が退院後に遭遇する困難

\begin{tabular}{|c|c|c|}
\hline カテゴリー & サブカテゴリー & - \\
\hline \multirow[t]{2}{*}{ 1. 病気の不確实性 } & 1) 死奺んじゃないかとの不安 & 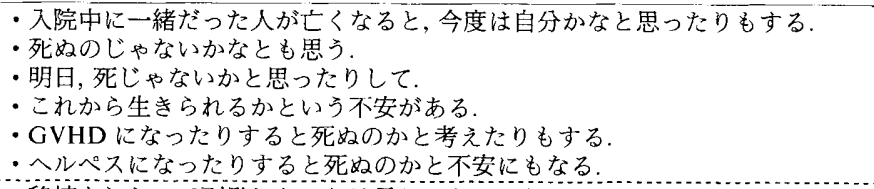 \\
\hline & 2) 再発に対する不安 & 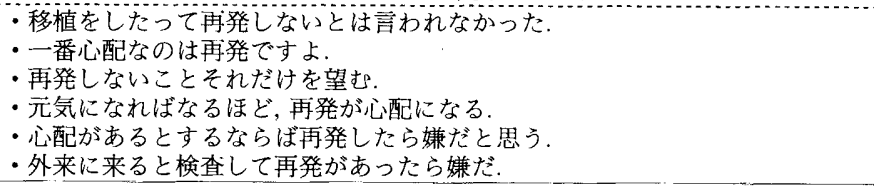 \\
\hline \multirow[t]{2}{*}{$\begin{array}{l}\text { 2. 変化した生活が辛く衰 } \\
\text { しい }\end{array}$} & 1) 仕事ができないことが辛い & $\begin{array}{l}\text { ・長期になって,働けないから辛い. } \\
\text { ・仕事ができないので妻に負い目を感じる. } \\
\text { ・就職したが病気になり首になったことが辛い. } \\
\text { ・仕事がこれからだとおもった先に病気になり,辛い. }\end{array}$ \\
\hline & 2 ) 収入が減り哀しい & 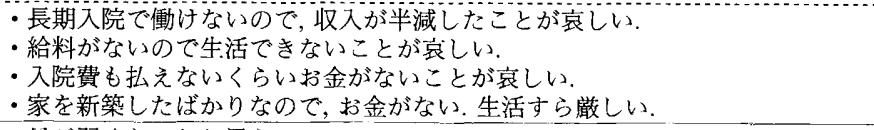 \\
\hline \multirow[t]{3}{*}{ 3、今までと違う体力 } & 1）休まないと仕事ができない & 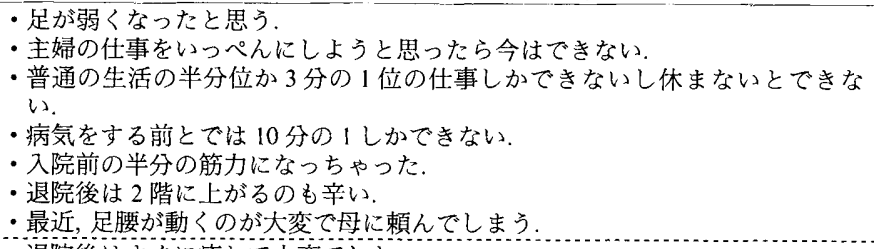 \\
\hline & 2)すぐに疲れる & 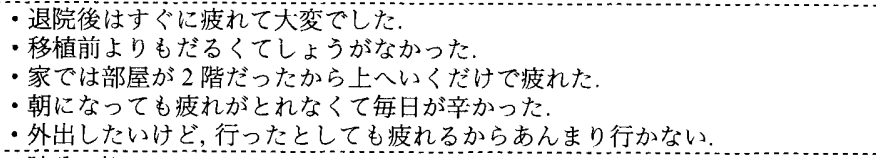 \\
\hline & 3) 体重が減つた & 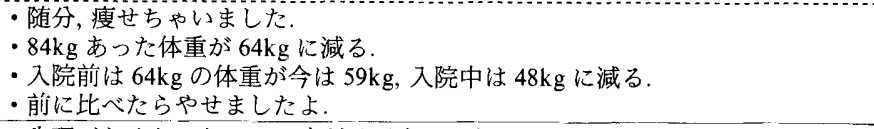 \\
\hline \multirow[t]{3}{*}{ 4. 身体的な変化 } & 1）女性性の衰失 & $\begin{array}{l}\text { ・生理がなくなったことで楽だけど女じゃないみたい. } \\
\text { ・供ができなくなる話は聞いていたが生理がなくなるとは思っても見なかっ } \\
\text { た.女性じやないみたいで. }\end{array}$ \\
\hline & 2 ) 性欲の減退 & 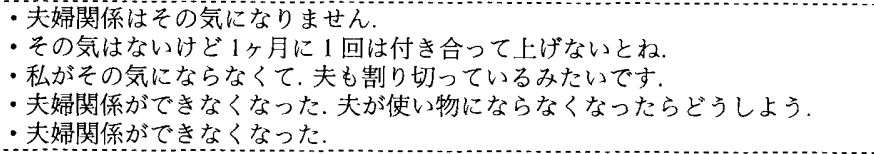 \\
\hline & 3) 外観の変化 & 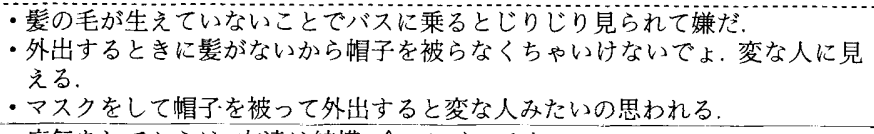 \\
\hline \multirow[t]{2}{*}{ 5. 周囲への気兼ね } & 1) 元気な人とは分かり合えない & $\begin{array}{l}\text { - 病気をしてからは, 友達は結構, 会いにくいみたい. } \\
\text { ・高校時代子とかとは, 病気をしてからは会わない. } \\
\text { ・病気のこといってもわかってもらえないでしょう. } \\
\text { ・友人とも病気をする前とでは構えてしまう. } \\
\text { - 小さな町だから病気扱いされて特別扱いされるのが嫌です. } \\
\text { - 病気のことは,元気な人に話してもわかってもらえない. }\end{array}$ \\
\hline & 2) 病気のことで心配をさせたくない & $\begin{array}{l}\text { ・主人にはあまり相談しません. } \\
\text { ・あっちが痛いとかいうと心配かけるのでいえない. } \\
\text { ・主人や娘だとびっりしてしまうからあまり相談しない. } \\
\text { ·親の前ではちゃんとしなくてはと思う. } \\
\text { ・妻は弱いので心配かけたくない. } \\
\text { ・だんなも,相談されたくないみたい. }\end{array}$ \\
\hline
\end{tabular}


た人が亡゙くなると，今度は自分かなと思ったりもする」 のコードから同病者の死に遭遇し自分と重ね合わせたこ とや移植合併症の出現で死を意識しながら生活すること を意味していた。

〔再発に対する不安〕は, 移植治療で病気が完全に治癒 する保証のないことと原疾患が悪性であり, 再発するこ とが死を意味することからの不安であった。

『変化した生活が辛く哀しい』のカテゴリーは〔仕事 ができないことが辛い〕〔収入が減り哀しい〕というサブ カテゴリーから構成されていた．このカテゴリーが意味 することは, 闘病生活が長引き仕事に行けないことや職 を失ったことで収入の減少があり, 生活を支えていた役 割が果たせなくなったことからの精神的な困難であった。

『今までと違う体力』のカテゴリーは,「退院後は 2 階 に上がるのも辛い」「朝になっても疲れがとれなくて毎日
が辛かった」とのコードから〔休まないと仕事ができな い〕〔すぐに疲れる〕〔体重が減った〕というサブカテゴ リーから構成されていた。

『身体的変化』のカテゴリーは, 移植を受けたことで生 じる，抗がん剂の副作用や移植合併症から来る身体機能 の障害であり，〔女性性の表失〕〔性欲の減退〕〔外観の変 化というサブカテゴリーから構成されていた.

『周囲への気兼ね』のカテゴリーは，2つサブカテゴ リーから構成されていた。

〔元気な人とは分かり合えない〕は, 原疾患自体が悪性 であることや移植自が特別な治療のように感じているこ とで周囲の人分かち合えないことであった．

〔病気のことで心配をさせたくない〕は,病気のことを 話すことで身近な人に心配させたくないと思う気持ちを 意味していた。

表 3 移植後の生活を再構築できる要因

\begin{tabular}{|c|c|c|}
\hline カテゴリー & サブカテゴリー & - \\
\hline \multirow[t]{2}{*}{ 1．前向きに生きる決意 } & 1) 前向きに生きなければと思う & 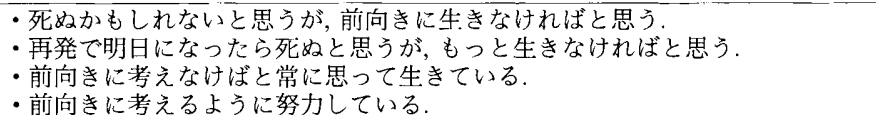 \\
\hline & 2) プラス思考比よう & $\begin{array}{l}\text { ・プラスに考えようと努力している. } \\
\text { ・プラス思考になるうと思って生きている.マイナス思考はしてはいけない. } \\
\text { ・マイナス思考をするといいことがなのでがんばってプスに考える. }\end{array}$ \\
\hline \multirow[t]{2}{*}{ 2. 大婦の価値観の変化 } & 1) 精神的な結び付きが大切 & $\begin{array}{l}\text { ・肉体的な関係だけがつながりじゃないから気持ちの結びつきが大事. } \\
\text { ・できないが夫婦のつながりは前より強いかもね. } \\
\text { ・体の関係以上のつながりを体験できた. } \\
\text { ・肉体だけじゃないから夫婦はね. }\end{array}$ \\
\hline & 2)関係がくても変わらない & $\begin{array}{l}\text { ・夫婦関係はできないから変わるものではない.気持ちは変わらない. } \\
\text { ・関がなくても婦は変わらない. } \\
\text { ・できなから別にかわらない. }\end{array}$ \\
\hline \multirow[t]{2}{*}{ 3. 自分のペースで生活 } & 1)できないことは他者に依存する & $\begin{array}{l}\text { ・娘もいるし,できないことは妻と娘に頼む. } \\
\text { ・足腰が弱ってしまって母に依頼する. } \\
\text { ・退院後は家族が見てくれる. }\end{array}$ \\
\hline & 2)自分で調整しながら元の生活に紊す & $\begin{array}{l}\text { ・短時間の散步からほ沈める. } \\
\text { •うちで気ままに過ごしている. } \\
\text { •家事をしながら休み休みする. } \\
\text { ・セーブしながら前の6 割くらいでやる. } \\
\text { ・肉体労働でないから疲れたら休むようにしている. }\end{array}$ \\
\hline \multirow[t]{2}{*}{ 4. 経済生活の基盤の変化 } & 1) 妻の収入で生活する & $\begin{array}{l}\text { ・自分が仕事ができないので, 妻が働きはじめた. } \\
\text { ・収入が減ったので女房が動き始めた. }\end{array}$ \\
\hline & 2) 蚺親からの支援で生活する & 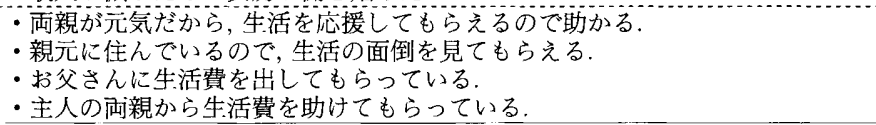 \\
\hline \multirow[t]{3}{*}{ 5。苦悩を支えられた体験 } & 1)辛い気持ちを受容 & 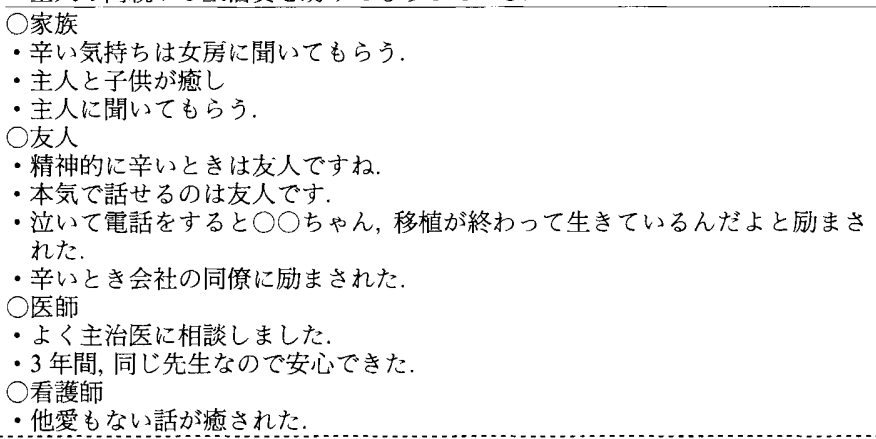 \\
\hline & 2)同一体験を共感 & $\begin{array}{l}\text { ○移植体験した人 } \\
\text { ・同一体験をした人は, 電話をしたりして同級生みたいです. } \\
\text { 今の症状を,いつ治ると聞くと, 必ずなおると言われるとすごく気持ちの支え } \\
\text { になる. } \\
\text { ○一緒に入院した人 } \\
\text { ・-緒に入入院した人は外来時, 電話などで苦しみをしっているので理解してく } \\
\text { れます. } \\
\text { ・同じ部屋の人とはよく話します, 支えになります. }\end{array}$ \\
\hline & 3) 専門的な助言 & $\begin{array}{l}\text { O医師 } \\
\text { ・病状を聞いて, 順調と言われるのが一番うれしいる } \\
\text { ・先生のおっしゃる通りにしてきたことがよかった. } \\
\text { ・調子が悪いときは先生に相談できてよかった. }\end{array}$ \\
\hline
\end{tabular}




\section{移植後の生活を再構築できる要因 (表 3)}

『前向きに生きる決意』『夫婦の価値観の変化』『自分 のペースで生活』『経済生活の基盤の変化』『苦悩を支光 られた体験』の 5 つのカテゴリーが抽出された．以下の 要因について説明する.

『前向きに生きる決意』のカテゴリーは, 病気自体が曹 性疾患であること，移植が辛い体験をしながら生活して いたが肯定的な考え方をする決意をしたことから〔前向 きに生きなければと思う〕〔プラス思考にしよう〕のサブ カテゴリーが見いだされた。

『夫婦の価值観の変化』のカテゴリーは, 病気をしたこ とで夫婦関係が心と心の結びつきを大切にするように なったことから〔精神的な結び付きが大切〕〔関係がなく ても変わらない] のサブカテゴリーが見出された．

『自分のペースで生活』のカテゴリーは, 移植をしたこ とで生じた『今までと違う体力』を受容したことから自 分のペースがつかめ〔できないことは他者に依存する〕

〔自分で調整しながら元の生活に戻す〕のサブカテゴ リーが見出された。

『経済生活の基盤の変化』のカテゴリーは, 療養生活の 長期化により仕事ができないことから収入源が患者から 他の家族へ変化したことから〔妻の収入で生活する〕〔軕 親からの支援で生活する」のサブカテゴリーが見出され た.

『苦悩を支えられた体験』のカテゴリーは, 移植患者が 退院後に苦悩を支元られた体験が〔辛い気持ちを受容〕

〔同一一体験を共感〕〔専門的な助言〕のサブカテゴリーに 見出されるような支援があった。

\section{考察}

造血幹細胞移植患者が退院後に遭遇する困難と移植後 の生活を再構築できる要因を分析してきた，その結果か ら移植患者が退院後の生活を円滑に過ごせるような看護 実践について以下に考察する。

造血器腫腸患者にとって移植は, 生きる希望であり明 るい未来への可能性を持てる治療である. ${ }^{11}$ しかし, 本研 究の結果から移植を受けた患者は, 原疾患からくる困難, 移植治療に伴う合併症からくる身体症状が原区，さらに 治療期間が長期になることで退院後に困難に遭遇してい たことが明らかになった。

患者は, 移植前に医師から移植治療の安全性と危険性 と移植治療を受けことでの生存率まで説明される。そし て移植を受けても100\%完治する保障のないことを自覚 することから，『病気の不確実性』を体験していた。これ は Mishel ${ }^{21}$ の指摘している予後不良息者は，先の見通し がつかないときに不確かさを経験すると述べている. 本 研究の結果は，移植治療をしても原疾患が治癒すること
への不確実性を表したもので患者は，『死』や『再発』へ の不安を持ちながら生活していることが明らかになっ た．移植治療は「辛さ」「苦しさ」に耐光，死を意識する

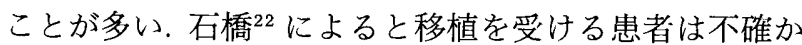
さと共存しょうと対処し，不確かさのある状態で耐える ことで新しい見解や方向性を見出すことにつながると述 べている.この石橋が述べた新しい見解が, 本研究の結 果では〔前向きに生きなければと思う〕〔マイナスし思考 をしない〕からなる『前向きに生きる決意』であり,看護 師は患者が前向きに生きられるようなサポートが大切て あると考えられる. Syrjala ${ }^{23}$ は，移植後に患者がサポー トグループに参加する事で困難感が緩和すると報告され ている.このようなサポートグループを作ることが必要 であると考光る

『今までと違う体力』は, 無菌室への長期間の入室から 来る行動範囲の減少であり運動量もすくないことによる 体力低下が考元られる。移植注前処置の大量の抗がん棛 や全身照射により強い骨髄抑制が起こり易感染状態とな

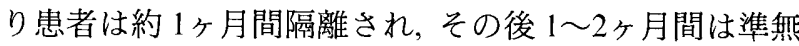

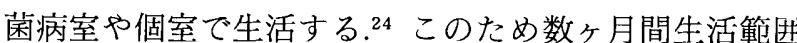
が非常に狭くなり運動範荆が減少する。〔〔休まないと仕 事ができない〕〔すぐに疲れる〕で表現された倦急感は移 植後に最も頻度の高い重要な症状である.25〔できないこ とは他者に依存する〕や〔自分で調整しながら元の生活 に戻すりなど自分のぺースで生活する能力を見出してい た。〔すぐに疲れる〕ことは，化学療法の副作用からくる 倦㤐感であるが筋力低下は，無菌室という狭い環境で行 う移植治療からくる特徴的な困難であるといえよう Schwartz ${ }^{26}$ はがん化学療法息者の倦急感に対して定期的 な運動を行うことで軽減すると報告している，日本では 渡辺 ${ }^{27}$ が準無菌室で行う骨髄移植患者に早期から段階的 に運動を行ったところ僚㤐感, 精神的な改善し運動が有 効であることを明らかにしている。しかし，無菌室内で 運動の効果を検証した研究は見当たらないことから，移 植を受ける患者への筋力低下予防を目指す看護介入が移 植患者看護にとっては急務であると考える。

移植後は GVHD, 感染症, 臟器障害, 原疾患の再発など の危険性が高く, ${ }^{28}$ 慢性的で長期的な合併症が加わり社 会復帰には時間がかかることで療養生活が長期化するこ とで生じる『変化した生活が辛く哀しい』が生じている． 闘病生活の長期化が一-家の大黒柱である息者が〔仕事が できない〕[収入が少なくなり家族を支えられない〕こと が困難になっていたこのことで，『経済生活の基盤の変 化』で, 移植後の生活を再構築していた，役割交代は，患 者にとって不本意な生活の変化であったことが同える. 脊や両親などの支援で生活することになったことで，息 者にとって自尊心の低下が予測される体験である. 
『身体的変化』の中の〔女性性の岥失〕〔性欲の減退〕 は, 日本造血細胞移植学会による移植時年齢分布統計 ${ }^{29}$ によれば, 半数以上が 29 歳以下の若年者であり,この年 代は結婚し家族を作ることが重要な発達課題である.移 植を受けた患者の性機能障害の頻度は高く, ${ }^{30}$ 移植患者 は不妊や閉経などがあり家族のサポートでは解決できな い個人の葛藤であり，家族関係が良好でも性生活の満足 が得られない事がある. ${ }^{31}$ 患者の中には, 夫婦関係におけ る性生活に対し『夫婦の価值観の変化』を体験し,精神的 な結び付きを大切にしている患者もいる. 肉低的な結び つきのみならずパートナーとの親密性を形成していくこ とが大切であり，医療チームで支援していく課題である.

移植は, 移植前に腫瘍根絶を目的に大量の抗がん剂が 投与され，全身照射がなされ非常に強い身体的な侵襲を 伴うリスクの高い治療である. そのため入院中から身体, 精神面においてつらいことが多い治療である，その辛い 中で患者は『苦悩を支えられた体験』ことが明らかになっ た. 本研究の結果からは〔辛い気持ちを受容〕〔同一体験 を共感〕〔専門的な助言〕のサポートを患者は体験してい たすすなわち，移植に対する脅威度は移植前の医療者の 情報的サポートよりも情緒的サポートを強化することで

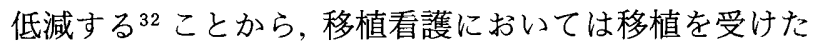
患者が退院後の生活を再構築できるような患者を支える サポートを行うことが重要である.

本研究の限界は, 移植を受けた患者が退院後に遭遇す る困難な体験は，主観的な体験であることから出来るだ け患者をありのままの捉えようと試みた。しかし，質的 研究であり研究者が対象者に影響を与えなかったとは言 いがたい，今後は，本研究の結果を基に，患者を支える家 族の遭遇する困難な体験に迫り，多角的なデー夕を積み 重ね，移植看護をより精選された援助を行うことが課題 である．また，移植看護において看護介入を検討するこ とは, 今後の課題である.

尚, 本研究は『11th International Conference on Nursing 2000 (第 11 回国際がん看護学会)』で発表したもの を再構成したものである.

\section{謝 辞}

本研究のデー夕収集にご協力をいただきました患者 様, 血液内科病棟の皆様に心より感謝申し上げます。

また，本論文を執筆するにあたりまして，群馬大学医 学部附属病院 総合診療部教授 田朴遵一先生にご支援 いただきましたことを心より感謝致します。

\section{文献}

1. 松田光信, 須磨あい子, 入田紀子ら. 造血肝細胞移植 を受けた患者が認識する無菌室中での看護師から受
けたケア. 日本看護学会誌. $2002 ； 12 ： 13-24$.

2. 富田恵理. 無菌室退室後における骨髄移植患者のス トレス認知とコーピング. 神奈川県立看護教育大学 校看護教育研究集録. $2001 ； 26 ： 287-294$.

3. 石川豊子, 渡辺真理, 小野寺綾子ら. 無菌室入室中に 精神症状を呈した患者の看護 Fink の危機モデルを 用いて分析する． 日本がん看護学会誌. $1992 ； 16$. 65-69.

4. 近藤咲子, 西平万知子, 小島明子. 同種幹細胞移植患 者の prospective な QOL の評価 SF36, HAD, BHS を用いて。造血幹細胞移植学会看護吥究集録集. $2002 ; 25: 13-15$.

5. 坪田千里，十河幸代，西出ひとみら，骨髄移植患者の 退院後の QOL -3 年後の追跡調査を行って一. 旭川 赤十字医誌. $1997 ;$ 53-57.

6. 米沢禎子, 杉山早苗, 細野玲子ら. 骨髄移植患者の退 院後の QOL と退院指導の検討. 旭川赤十字医誌 $1993 ; 69-75$.

7. 黒沢真澄, 大野 裕, 岡本信一郎. 骨髄移植に関する 心理的サポートについて. 心療内科. 1997；69-75.

8. 米沢禎子, 中野清美, 市村方子ら. 心理テストを用い た骨髄移植患者の心理の理解 第 1 報. 旭川赤十字 医誌. $1994 ； 52-56$

9. 早坂瑞樹, 福田朋子, 加瀬加寿美ら. 造血幹細胞患者 に対する事前オリエンテーションの特殊形態 (無菌 室宿泊体験入室）に関する考察. 第 26 回日本造血幹 細胞移植学会看護研究収録集. $2003 ; 185$.

10. 石田和子, 下田 薰, 中村美代子ら. 骨髄移植患者の 退院後に扔ける適応問題の分析. 群馬保健学紀要. $1999 ; 20: 41-47$.

11. Usama S. Saleh, Dorothy Y. Brokopp. Hope among patients with cancer hospitalized for bone marrow transplantation. Cancer Nursing. 2001; 308-314.

12. Rita Secola, MSN, RN, CPON. Hematopoietic stem cell transplation a gimpse of the past and view of the future. Jounal of Pediatric Oncology Nursing. $2001 ; 18: 171-177$.

13. Haberman M. The meaning of cancer therapy, bone marrow transplantation as an exemplar of therapy. Seminars in Oncology Nursing. 1995; 23-31.

14. R. H. Belec. Quality of life, Perceptions of longterm surviors of bone marrow transplantation. Oncology Nursing Forum. 1992; 37.

15. 古賀美佐子, 塚原恵子, 尾上裕子ら. 同種移植 (BMT) 後の Quality of Life (QOL) に関する検討. 看護技術. 1994; 103-108. 
16. 外崎明子. わが国の造血細胞移植患者のヘルスプロ モーションにおける看護支援の展望. 日本がん看護 学会誌. $2003 ; 17: 4-12$.

17. Polit, D.F. \&Hungler, BP. (近藤潤子監訳) : 看護研 究一原理と方法一 東京医学書院. 1994: 266.

18. Krippendorff K (三上俊治他訳)：メッセージ分析 の技法「内容分析」への招待. 勁草書房. 2001.

19. Chenitz W.G (樋口康子他監訳)：ラウンデッド・セ オリー看護の質的研究のために. 医学書院. 1997.

20. 木下康仁：グランデット・セオリーアプローチ 質 的実証研究の再生. 弘文堂, 1999.

21. Mishel, MH. Uncertainty in illness. IMAGE Scholarship. $1989 ; 225-232$.

22. 石橋美和子. 同種骨髄移植を受ける患者の不確かさ とその対処. 日本がん看護学会誌. 2003；16：5-14.

23. K.L. Syrjila, M.K. Chapko, P.P. Vitalino, et al. Recovery after allogenic marrow transplantation . prospective study of predictoros of longterm psysical and psychosocial function. Bone Marrow Transplantion. $1993 ; 11: 319-327$.

24. 藤井宝恵, 児玉和紀, 岡田浩佑ら. 無菌室入室中の急 性骨髄性白血病患者における QOL の変化とその要 因. 日本看護研究学会雑誌. $2003 ； 101-110$.

25. Persson L, Hallberg IR, Ohlsson O. Survivors of acute leukemia and highly malignant lymphoma. retrospective views of daily life problems during treatment and when in remission. Journal of
Adovanced Nursing. $1997 ; 25,68-87$.

26. Schwartz A L. Physical activity and exercise in the management of cancer-related fatigue. 看護研究. $2003 ; 79-85$.

27. 渡辺力チ子, 安藤裕子. 無菌室入室㭧者の日常生活 活動援助一患者意欲を中心とした運動の効果一- . 看 護総合 (日本看護協会出版会)。1997；28：205-208.

28. Usama S, Saleeh, Dorothy Y, at all. Quality of life one year following bone marrow transplantation . psychometric evaluation of the quality of life in bone marrow transplant survivors tool. SALEH. 2001; 1457-1461.

29. 日本造血細胞移植学会全国デー夕集計事務局. 将成 14 年度全国調查報告書. 2002.

30. E.M. Altmaier, R.D. Gingrich, M.A. Fyfe. Twoyear adjustment of bone marrow transplant surviors. Bone Marrow Transplantation. 1991 ; 7 : 311-316.

31. A. Molassions, O.B.A. vandenAkker, B.J. Boughton. perceived social support, family environment and psychosocial recovery in bone marrow transplant long-term surviors. Soc. Sci. Med. 1997; 44 : 317 325.

32. 外崎明子. 造血細胞移植を受ける患者の心理的安定 に関する縦断的研究一その 1 移植の重要とその関 連要因の検証. 日本がん看護学会誌. $2004 ； 18 ： 3$ 13. 


\title{
The Difficulties and Factor by Construct Discharged Bone Marrow Transplantation Patients on daily life
}

\author{
Kazuko Ishida, ${ }^{1}$ Kaoru Hagiwara, ${ }^{1}$ Junko Ishida, ${ }^{2}$ \\ Misayo Akaishi, ${ }^{2}$ Kumiko Yoshida, ${ }^{2}$ Kazue Hirai, ${ }^{3}$ \\ Etsuo Kawada ${ }^{4}$ and Kiyoko Kanda ${ }^{5}$
}

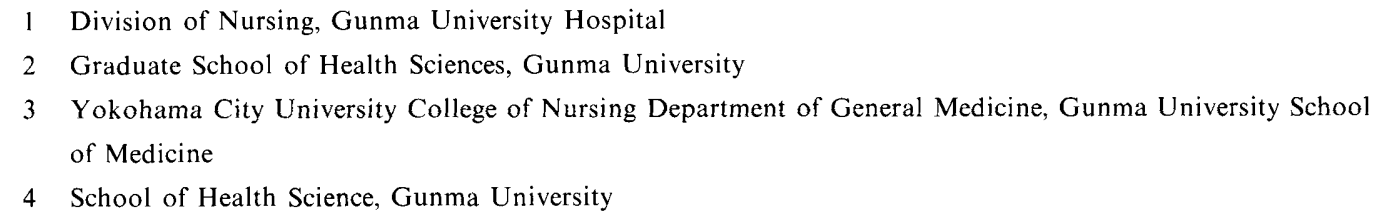

Background and Aims : These measures, however, give stress to the patients in their daily life. This study aims at identifying the way to make it easier for them to adapt after being discharged from the hospital. To identify the problems the patients face in adapting to their daily life after discharge from the hospital. Methods : Thirteen patients ( 5 male and 8 female) who received allogenic bone marrow transplantation or periferal blood stem cell transplantation and who have not shown any loss of survival of the graft. Qualitative study using quasiconstitutive interview. Interviews were performed for 30 minutes to 1 hour in a private room to keep privacy of the patients. The conversations (one for a patient) were tape recorded with the patients' permission and transcribed. Analytical method: Record of the interview was analysed and words and behaviors suggesting problems in daily life were coded. The similar codes were then categorized. Results: The Difficulty daily life after discharge from the hospital, Five categories are interrelated as shown in the figure and they can be used to make a model of problems. The patients tend to have negative feelings toward themselves. Factor by Construct daily life after discharge from the hospital, Five categories are interrelated. Conclusion : On the other hand, the experience of transplantation has made them realize importance of life and try to live positively. They have to be supported so that they can be confident in living in the society. (Kitakanto Med J 2005 ; $55: 97 \sim 104)$

Key words: Bone Marrow Transplantation Patients, daily life, after discharge from the hospital, The Difficulties and Factor by Construct. 